\title{
Vascular dysfunction : at the heart of cardiovascular disease, cognitive impairment and depressive symptoms
}

Citation for published version (APA):

van Sloten, T. T. (2015). Vascular dysfunction : at the heart of cardiovascular disease, cognitive impairment and depressive symptoms. [Doctoral Thesis, Maastricht University]. Maastricht University. https://doi.org/10.26481/dis.20150520ts

Document status and date:

Published: 01/01/2015

DOI:

10.26481/dis.20150520ts

Document Version:

Publisher's PDF, also known as Version of record

Please check the document version of this publication:

- A submitted manuscript is the version of the article upon submission and before peer-review. There can be important differences between the submitted version and the official published version of record.

People interested in the research are advised to contact the author for the final version of the publication, or visit the DOI to the publisher's website.

- The final author version and the galley proof are versions of the publication after peer review.

- The final published version features the final layout of the paper including the volume, issue and page numbers.

Link to publication

\footnotetext{
General rights rights.

- You may freely distribute the URL identifying the publication in the public portal. please follow below link for the End User Agreement:

www.umlib.nl/taverne-license

Take down policy

If you believe that this document breaches copyright please contact us at:

repository@maastrichtuniversity.nl

providing details and we will investigate your claim.
}

Copyright and moral rights for the publications made accessible in the public portal are retained by the authors and/or other copyright owners and it is a condition of accessing publications that users recognise and abide by the legal requirements associated with these

- Users may download and print one copy of any publication from the public portal for the purpose of private study or research.

- You may not further distribute the material or use it for any profit-making activity or commercial gain

If the publication is distributed under the terms of Article 25fa of the Dutch Copyright Act, indicated by the "Taverne" license above, 


\section{Valorization addendum}

One of the main tasks of Universities is to ensure that research findings impact society, i.e. valorization. This addendum discusses the valorization potential of several main findings of the present thesis: the findings that vascular brain damage is an important risk factor for late-life depression, and that arterial stiffness and microvascular and endothelial dysfunction may lead to vascular brain damage.

\section{Relevance of the findings}

Life expectance in the Netherlands and much of the rest of the world has dramatically increased and will continue to do so in the next decades. Depression and depressive symptoms are often present in older individuals, and pose an enormous emotional and economic burden to individuals, families and health care systems. There is, thus, a growing need to understand their causes. The investigation of such causes will help to identify targets for prevention and treatment of late-life depression. The present thesis strongly suggests that damage of the small arteries in the brain (cerebral small vessel disease) is an important risk factor for late-life depression. The underlying mechanism is that vascular damage may lead to depression via disruption of brain structures involved in mood regulation.

The identification of vascular brain damage as a potential cause of late-life depression will have societal impact. Indeed, this finding suggests that efforts at favourably influencing vascular damage can have significant public health implications via prevention and treatment of depression. However, before this finding can be translated into treatment strategies, further research is warranted. Currently, it is incompletely understood which factors contribute to cerebral small vessel disease, and whether such factors can be therapeutic targets for late-life depression. This addendum therefore includes a proposal for further observational studies and clinical trials, and discusses how the findings of this research can lead to new prevention and treatment strategies of depression.

\section{Future research: observational studies}

The findings presented in this thesis suggest that several (interrelated) processes may lead to cerebral small vessel disease and depression, including arterial stiffness and microvascular and endothelial dysfunction. These findings were, however, based on crosssectional studies. This precludes any conclusions about a temporal association of arterial stiffness and microvascular and endothelial dysfunction to cerebral small vessel disease and depression. Furthermore, in the present thesis information was available on depressive symptoms only, but not on clinical depression. The investigation of depressive 
symptoms is important as it contributes to understanding the pathogenesis of depression. However, depressive symptoms do not necessarily reflect underlying disease or lead to future disease, and their clinical value is currently not fully understood. Future studies are, therefore, warranted to evaluate whether the observed associations for depressive symptoms are also true for clinical depression.

In view of the above, we propose to use cross-sectional and longitudinal data of The Maastricht Study to evaluate the association between arterial stiffness and endothelial and microvascular dysfunction on the one hand and cerebral small vessel disease and depression on the other. The Maastricht Study is a large, longitudinal observational study conducted in Maastricht and is expected to become one of the most extensive phenotyping studies worldwide. The Maastricht Study focuses on the investigation of causes of type 2 diabetes and other chronic diseases, including depression. The study uses state-of-the-art imaging techniques and extensive biobanking to determine the health status in a population-based cohort of 10,000 individuals that is enriched with individuals with type 2 diabetes aged between 40 and 75 years. Enrolment of participants of The Maastricht Study started in November 2010 and is anticipated be complete in the end of 2015 / beginning of 2016. After this period, a follow-up examination round will be done. The results of cross-sectional and longitudinal data are expected to be available in 2016 and 2020, respectively. In this study, depressive symptoms and depression are evaluated by questionnaire and by a structured interview conducted by trained investigators. In addition, participants undergo a magnetic resonance imaging (MRI) investigation of the brain to evaluate the presence of cerebral small vessel disease. Arterial stiffness, in turn, is determined at different sites and segments, and with use of different techniques. These include the determination of segmental aortic stiffness with use of carotid-femoral pulse wave velocity, and assessment of local carotid, femoral and brachial artery stiffness by vascular ultrasonography. In addition, detailed measurements are done of the function and structure of the microvasculature and endothelium of both the skin (e.g. capillaroscopy and Laser Doppler flowmetry) and retina (e.g. funduscopy and dynamic retinal vessel analyzer). Furthermore, endothelial dysfunction is assessed by the determination of endothelial-derived blood biomarkers.

An important merit of The Maastricht Study is the oversampling of individuals with type 2 diabetes. This allows investigating any potential contrast between individuals with and without type 2 diabetes in the association between arterial stiffness and microvascular and endothelial dysfunction and cerebral small vessel disease. Individuals with type 2 diabetes have a greatly increased risk of cerebral small vessel disease and depression, possibly in part because these individuals may be particularly prone to the detrimental effects of increased arterial stiffness on the cerebral vasculature. In the next years, we will apply for research grants to conduct the research as outlined above. 


\section{Future studies: randomized clinical trials}

In addition to observational studies, future large (multi-centre) randomized clinical trials are needed that evaluate the effects of favourably influencing arterial stiffness and microvascular and endothelial dysfunction. Such trials need to take into account the potential beneficial treatment effects on depression. For instance, depressive symptoms can be used as a secondary end point and/or the effects of treatment on depressive symptoms can be evaluated in a substudy of these trials. Several interventions are available that have a favourable influence on arterial stiffness and endothelial and microvascular dysfunction, including lifestyle modifications, such as weight loss, increased physical activity and dietary modifications, and drugs, such as (long-term) blockade of angiotensin receptor- 1 antagonists and angiotensin receptor-2 agonists. These drugs may lower arterial stiffness, possibly beyond any blood-pressure lowering effects. Currently, no trials on arterial stiffness and microvascular and endothelial dysfunction take into account depression or depressive symptoms. We will try to create awareness of this issue among researchers in the field via publication of articles in peer-reviewed journals on this topic and via presentations at scientific meetings, such as the meetings of the Artery Society and the European Society of Hypertension.

\section{New treatment strategies for late-life depression}

Currently, treatment for almost all older patients with depression or depressive symptoms includes antidepressant medication and/or psychotherapy. The findings of the present thesis, if confirmed in The Maastricht Study and clinical trials, indicate that favourably influencing arterial stiffness and microvascular and endothelial dysfunction are new strategies for prevention and treatment of depression, in particular in older individuals. It is, however, likely that only a subset of older patients with depression have vascularrelated disease. Determination of arterial stiffness (e.g. carotid-femoral pulse wave velocity) or endothelial dysfunction (e.g. brachial artery flow-mediated dilatation) in older patients may help to select these individuals, which could help guide treatment choices and tailor interventions to the individual patient. Thereby, the identification and treatment of vascular-related depression can be a first step toward personalized medicine in (geriatric) psychiatry. 